\title{
MASSIVE SUBSIDIES AND ACADEMIC FREEDOM
}

\section{RUSSELL KIRK*}

To kill through kindness is quite possible. Although some of the old causes of insecurity in academic freedom have diminished considerably in recent years, new influences are at work which-even granting the benignity of the intentions involved-may produce difficulties less susceptible of remedy.

As Tocqueville remarked of "democratic despotism," the impalpable pressures of a prosperous mass society can be more oppressive ultimately-and harder to resist successfully-than the arbitrary measures of the autocracies of yesteryear. The English and Scottish universities have endured through the centuries-most of the time-with a high degree of academic freedom, in considerable part because their permanent endowments were sufficient to provide for their annual expenditures. (Only since World War II have they come to depend for half their revenues upon governmental grants.) It is only seemingly a paradox that in a "democratic" age educational institutions are better provided with cash than ever they were beforeand yet exhibit less independence and strength of opinion than they did in less egalitarian times.

For no proverb is truer than this, that "The man who pays the piper calls the tune." If educational institutions become dependent for their increase of reputation, or perhaps even for their existence, upon a few sources of benefaction, ineluctably most administrators and even professors will play their pipes accordingly. And this is not the less true merely because a government is "democratic," or a 'foundation "charitable." Governments and foundations are directed by men, like all of us, with prejudices and interests-which may not always be identical with the opinions and advantages of the more lively spirits in the Academy.

President Nathan S. Pusey, of Harvard University, recently spoke of certain 'distortions suffered by his university because of its participation in federal programs of scientific research. Institutions less well prepared to defend themselves than 'Harvard may experience greater discomfort, when confronting the benefactions and the demands of the Department of Defense or of the Ford Foundation. At the University of Louisville, for instance, all eight doctoral programs in the graduate school are scientific, and are subsidized-nay, originated-by federal governmental activities. Need one labor the point that, potentially, a university is less free to make its own important decisions, under such circumstances?

Rather than analyzing at this moment in my brief essay the theoretical perils to academic freedom from such concentration of power, I offer some very recent

- B.A. 1940, Michigan State University; M.A. I941, Duke University; D.Litt. 1952, St. Andrews University (Scotland). Research Professor of Politics, C. W. Post College, Long Island University. Editor, The University Bookman (quarterly). Author, Academic FreEdom (r955); ST. ANDrews (1954); THE Conservative Mind (r953). 
case histories. The dangers to academic freedom are not remote: already, in certain institutions, conformity to the preferences and value judgments of the administrators of foundations and governmental agencies is being enforced. I refrain from naming institutions and scholars involved, because that would increase their difficulties. This point was made recently by Dr. John A. Howard, president of Rockford College: ${ }^{1}$

This is not a chimera born of a doctrinaire distrust of government. Recently I wrote to the president of a large well-known university inviting him to join a group of college presidents in making known the arguments against the ever-growing federal subsidies of education. He replied that although he was in full agreement with our position, that the subsidies are not in the long-range best interest of the colleges or the country, his own university was now so dependent upon funds from Washington that he could not exercise his rights as a citizen on this issue without jeopardizing the university he served.

Such uneasiness among university and college presidents may be discerned in their relationships with the great foundations, too. Some years ago, this writer addressed a national educational society-touching in his remarks, incidentally, upon the ideas of the former president of a foundation which, just a few weeks earlier, had bestowed large subsidies upon many colleges. Though my speech was well enough received by its audience of college administrators, it was not printed in that society's journal. I had disagreed on some points with this eminent benefactor: to publish such disagreement might seem ungrateful-or, more important, possibly, might discourage subsequent largesses from this foundation.

With the interests of certain universities and professors in mind, then, I delete in the following case histories the real names involved; but I have looked into these affairs with some care, and the facts are as I represent them below.

At one state university, the chairman of the the department of economics applied to a famous foundation for a sizable grant in support of a departmental research project. In his request, the chairman mentioned that his department believed in an economy of free enterprise. Now although the foundation in question had been established by a most individualistic entrepreneur, the functionaries of the foundation did not seem pleased by this attachment to doctrines shared by the deceased founder. On the contrary, the officers of the foundation informed the applicant for a grant that if his department generally held such views, it was "committed to a point of view," and therefore unworthy of benefaction. But should the chairman see fit to liberalize his department by introducing other opinions, the foundation secretary wrote, then it might be appropriate to apply again for a subsidy; and, indeed, the foundation would be willing to supply the chairman with the names of some promising young scholars whose employment in his department would relieve the monotony of "free enterprise" convictions.

Here the smugness and presumption of one sort of foundation administrator are sufficiently evident. No direct harm was done in this instance: the chairman had simply been admonished to alter his convictions, if he wanted money. But sometimes

\footnotetext{
${ }^{1}$ John A. Howard, in Widening Horizons, newsletter, Rockford College, Ill., April x963, p. 3.
} 
the interference of foundation-bureaucrats is more mischievous. The following episode is part of the history of the same foundation as that described above.

At a well-known private university, this big foundation awarded a subsidy to nearly all departments-with the conspicuous exception of the department of political science. Two or three members of this department, well-reputed scholars, were not in the good graces of the foundation. Also the foundation, on making this fat grant to the university, insisted on the appointment of a new administrative vicepresident nominated by the foundation itself. Under this altered academic regime, the political scientists who had ventured to disagree with the foundation's policies were cast into the outer darkness: one was appointed to a minor post equivalent to the Chiltern Hundreds, and another placed on an extended leave of absence, with the hint that he would do well not to return at all. Eventually, it appears, the department of political science will be favored with a grant-when it is wholly purged of deviant opinions.

Though these are especially disturbing examples of the increasing arrogance of foundations' influence in universities and colleges, a good many others might be cited. Only here and there does one encounter a department or even a university that cannot be bought for a price. And since at present the tendency of the foundationpersonnel is toward "liberal" social measures, the resistance of faculties to this honeyed interference is less strong than it would be if a big industrial corporation, say, were to make its gifts contingent upon a reform of policy and staff favorable to the corporation's prejudices and interests.

The consequences of large-scale benefaction by foundations upon the whole direction of advanced studies, and even upon undergraduate courses, are almost incalculable. Big subsidies may result in the virtual extinction of certain disciplines or schools of thought, supplanting these by opposing bodies of opinion or academic interests which it lavishly endows. Perhaps the clearest example of such radical alteration of academic disciplines is the immense growth of "behavioral studies" in political science and sociology, since World War II. Having determined to back the Behavioralists, foundations like Ford and Carnegie, in effect, have built enormous patronage empires for the behavioristic professors, with a corresponding loss of prestige and funds for those scholars who think the study of institutions or of theory should have pride of place over surveys of "behavior." The scholarships and assistantships go, for the most part, to the disciples of the behaviorist persuasion: thus the rising generation of teachers and researchers in such diciplines is indoctrinated in the foundation-favored wing of the social studies. ${ }^{2}$

Because as yet federal grants to higher education have been awarded only incidentally to humane and social studies, it is less easy to point to actions in this realm

'See Kirk, Growing Dangers in "Campus Research," N.Y. Times Magazine, Sept. r7, r96r, pp. 22 ff; also Kirk, Is Social Science Scientific? N.Y. Times Magazine, June 25, I96r, pp. I I ff.; and Kirk, Segments of Political Science Not Amenable to Behavioristic Treatment, in J. C. CharLesworth (Ed.), The Limits of Behavioralism in Politicaz Science 49-67 (ig62). 
which affect academic freedom. Among the physical and biological scientists, indeed, there exists already much concern over the increasing domination of the research field by governmental projects. Utilitarian and immediate objectives are favored over pure science and "basic" research, with consequent damage to both research and teaching in the universities. But though in the long run such a domination will touch upon questions of academic freedom, at present the trouble is only in a formative stage.

In those restricted fields of humane and social studies so far subsidized through the National Defense Education Act (NDEA), however, there is more immediate cause for vigilance. Take the language program under NDEA. The tendency of this project is to favor the rapid development of a shallow competence in language teaching, rather than to reinforce scholarship. The professors influential in such circles are the linguisticists, rather than the scholars of literature. And the federal funds employed tend to produce a levelling of learning, rewarding the mediocre departments and universities as well as the superior, offering a great number of scholarships -very fat scholarships-with no particular regard for the degree of real culture possessed by the applicants.

These matters bear directly upon academic freedom. The tendency of the federal Office of Education, for instance, has been to award scholarships almost without reference to the grades or judgment of the participating institutions-although the Office may back water when there are protests from distinguished professors. Also the Office of Education's people lend their authority to projects for producing a multitude of "college language teachers," in a hurry, who in turn will train a greater multitude of high-school language teachers-and to other schemes that produce statistical results fairly promptly, and increase the empire of Educationism. The better universities, confronted with a league between inferior institutions and the federal Office, grow disheartened; even representatives of long-established state universities hesitate to speak out against aggrandizement of this sort. More and more, decisions in this discipline are made from on high, and transmitted to departments of languages which may disagree with the general program-but comply, for the sake of the subsidy.

It is worth noting that my friends in such disciplines, when giving me information, invariably request that their names not be mentioned, should I write about the NDEA language-program. When anonymity is sought, even by distinguished scholars, academic freedom is in no prosperous state. Already, when some scholars have ventured in meetings to object to this or that feature of a language-scheme, there have been hints by NDEA zealots that Professors $X$ and $Y$ are not "good Americans," or they would go along. Scholars in languages are peculiarly susceptible to this type of intimidation, many of them, naturally, being foreign-born.

If federal subsidies are extended to the social studies, one may expect a great deal more of this exacting of conformity to grand designs, and more, too, of the 
struggle for power, along lines vaguely ideological. It is not a matter of direct interference by the White House with the opinions of professors-not at all; rather, the very nature of the centralizing process enables cliques and juntas to exert their will, increasingly, over those academics who tend to their learned knitting, instead of pursuing power and novelty.

"Whatever the solution to our pressing educational needs," writes President Douglas Knight, of Duke University,

... we must never hand over decisions about the direction of higher education to any one central committee. Centralization in this case might be just as dangerous as incoherence; and we have as much of an obligation to protect the "freedom of indifference" as we do to meet the obvious and enormous needs.

Through long experience, safeguards have been erected, in both state and private educational institutions, to resist pressures hostile to academic freedom from state and local authorities, business and industry, and other outsiders. But there are no present sure guarantees against the novel influence of foundations and of the federal government-the latter always operating from a position of central strength, and the bigger foundations often acting as centralized and centralizing agencies. The illustrations I have offered may suggest that a "central committee" concept of higher education is hostile to the real liberties of the Academy, as Dr. Knight argues. And the "freedom of indifference," which is one of the most valuable possessions of the Academy, has little notion of how to defend itself against these curious new adversaries whose weapon is the open-handed largess.

This writer offers, therefore, some general considerations upon the challenge to academic freedom latent in the growth of foundation-subsidy and governmentsubsidy. It is well to look a gift horse in the mouth.

(I) Ideological pressures must accompany these grants-in-aid. Ours is an age of ideology-which I distinguish from political philosophy and principle. From the central government, necessarily, will come demands for professors to be "good Americans"-and not to waste much time in the Ivory Tower. Many foundation staffs are strongly dominated by ideological prejudices-more commonly by what Dr. Sidney Hook calls "ritualistic liberalism" than by anything else. The particular character of the ideological inclination, in both government and foundations, may alter somewhat from decade to decade. But it never will be friendly toward the heirs of Socrates. Latter-day liberals, who at the moment embrace the cause of governmental grants on a grand scale, soon may find themselves the unhappy outsiders.

(2) These grand subsidies will tend to be utilitarian, at the expense of genuinely humane and scientific disciplines. Both the government and the foundations desire results easily tabulated and defensible. Scholars and subjects that do not contribute directly to military defense, "social betterment," or popular appetites will be allowed to wither on the vine.

\footnotetext{
${ }^{3}$ Douglas M. Knight (Ed.), The Federal Government and Higher Education igo (ig6o).
} 
(3) The administration of these benefactions must be bureaucratic, in the worst sense of that word. The remarkable dullness of the federal Office of Education is admitted by nearly everybody. The foundations have developed a strange selfperpetuating set of employees, sometimes more interested in their own salaries and their public-relations apparatus than in either cultural or material results. (One might demonstrate that, in some instances, the bond joining the managers of certain foundations is a common sense of guilt or inadequacy.) Both bureaucracies tend to resent unusual talents or insubordinate opinions among scholars.

(4) The power of these bureaucracies is more difficult to check or defy than that of other elements which, on occasion, are hostile to academic freedom. Private patrons sometimes were arbitary, true: but while one may discover, without much trouble, another millionaire, one never finds another government. ${ }^{4}$ The federal Office of Education and other federal agencies are more remote and conceited than are state legislatures. The great foundations, at once timid and complacent, tend to emulate one another-and what one disapproves, all foundations but a few obdurate little endowments tend to declare anathema. It is most unpleasant for a college or a scholar to be blacklisted by these bureaucracies, unless one has large private means. Diversity has been the principal virtue of the higher learning in America; but these are forces monolithic in character.

If one desires freedom, ordinarily one must make certain sacrifices. If you take the king's shilling, you must fight the king's battles. Most of our colleges and universities already squander a great deal of money upon fads, foibles, and boondoogles; nowadays they are not so desperately in need of more money as they fancy themselves to be.

I am suggesting that, rather than running after governmental and foundational subsidies, the Academy would do well to take such grants only after reflection-and only when certain that the largess is consonant with freedom of teaching and enquiry, calculated to raise the level of humane and scientific disciplines, and to respect the dignity of the scholar. King Stork, after all, was worse than King Log. Harvard University or the University of Chicago, Carleton College or Kenyon or Pomona, or Washington and Lee, will not preserve their virtues when they are suppliants for a dole. And their professors will not preserve their integrity.

\footnotetext{
'See Kirk, The Passing of the Patron, 97 America 64I (I957).
} 